\title{
Biodegradable Package - Innovative Purpose or Source of the Problem
}

\author{
Florentyna Markowicz ${ }^{1 *}$, Grzegorz Król², Agata Szymańska-Pulikowska' \\ 1 Institute of Environmental Engineering, Wroclaw University of Environmental and Life Sciences, \\ 50-363 Wroclaw, Grunwaldzki Square 24, Poland \\ 2 Waste Treatment Plant Sp. z o.o. in Jarocin, 63-200 Jarocin, Witaszyczki 1A, Poland \\ * Corresponding author's e-mail: florentyna.markowicz@upwr.edu.pl
}

\begin{abstract}
Neutralization of the amount of plastic packaging waste from year to year is becoming an increasingly serious problem. Replacing some of them with the products made of biodegradable and oxo-biodegradable polymers, which may be broken down in the environment in a shorter time seems to be one solution. Polymers are used both for the production of bags for biodegradable waste, as well as shopping bags, labeled by the producers as "compostable", "biodegradable", etc. Therefore, they are often used to collect bio-waste, with which they go to the installations intended for their processing, e.g. composting plant. However, contrary to the information on the package, not all are decomposed under the conditions prevailing in composting plants. The aim of this study was to assess the degree of decomposition of selected package from biodegradable and oxo-biodegradable polymers under the actual conditions of an industrial composting plants and the possibility of contamination of the product (compost) with components originating from, among others from the additives that improve the properties of plastics and dyes. The conducted research has shown that many bags and sacks available in retail chains, contrary to the information provided, are not completely degraded in industrial composting plants, and may also become a source of heavy metal pollution.
\end{abstract}

Keywords: packaging waste, biodegradable and oxobiodegradable polymers, composting, pollution

\section{INTRODUCTION}

Plastics are a material used all over the world in many branches of industry. They have gained popularity thanks to such features as: strength, durability, flexibility, and resistance to environmental factors. However, the growing use of plastics in industry is associated with the emergence of increasing amounts of waste. The beneficial and sought-after characteristics of plastics constitute a serious problem when they become waste. Therefore, an increasing emphasis is being placed on raising the amount of materials recycled and on reducing the amount of packaging used by consumers [Act of 13 June 2013, Jacobsen et al. 2018, Wróblewska-Krepsztul et al. 2018]. The way to reduce the amount of durable (thus resistant to decomposition processes) waste from conventional plastics may be the use in the production of biodegradable and oxo-biodegradable polymers [Bahramian et al. 2016, Spierling et al. 2018]. Biodegradable materials should decompose under the influence of macro- and microorganisms. The oxo-degradable plastics are also decomposed with the participation of living organisms, but the initiation of the process requires an additional factor (thermal energy, UV radiation). According to the assumptions of the creators [biodeg.org, epi-global.com, okcompost.be], these polymers are to meet the requirements of plastics, that is, they are to be durable and flexible, and at the same time when they are no longer usable, they should be biodegradable in the environment, i.e., in bedding, in landfill, in compost or soil.

One of the products made of biodegradable and oxo-biodegradable polymers are the bags 
for organic waste or shopping bags. Some of these products have the certificates confirming their compliance with European standards [EN 13432:2000, Wróblewska-Krepsztul et al. 2018], according to which, sacks (bags) should be $90 \%$ biodegradable within six months. Such products are marked as "compostable". On the other hand, sacks (bags) that were made using additives that ensure accelerated degradation in the environment (such as $\mathrm{d} 2 \mathrm{w}^{\circledR}$ or TDPA ${ }^{\circledR}$ ) are labelled by the producers as oxo-biodegradable.

The shopping bags made of oxobio- and biodegradable polymers, due to their different composition and properties, should not be recycled together with non-biodegradable plastics. They should be subjected to biodegradation under aerobic or anaerobic conditions [Álvarez-Chávez et al. 2012]. Therefore, they are often used to collect bio-waste with which they can be processed. They encourage, among others things, from the information provided on them, suggesting that the bags should decompose. Their users are convinced that they support environmental protection by reusing waste. Together with bio-waste, the bags are transferred to the biological treatment plant (e.g. composting plant), in which, contrary to the information provided by the producers, not all decompose, and they are not always successfully separated from the mass of waste during tearing and separation process. The substances included in the plastics, along with compost, can infiltrate into the soil environment and then water, causing pollution. Therefore, the permissible levels of impurities (chromium, cadmium, nickel, lead, and mercury) in fertilisers, also in composts made from wastes (classified as organic fertilisers) were defined [Regulation ... 2008].

The research on various types of plastics has indicated the presence of, among others, phthalates, chlorine, phosphorus, heavy metals (zinc, cadmium, lead, nickel, copper, chromium, cobalt, iron, manganese) [Lithner et al. 2011, Rochman et al. 2013, Tang et al. 2015, Pivnenko et al. 2016]. Among the additives used to manufacture plastics, there are: dyes, fillers, antioxidants, stabilizers, softeners, which can be a source of heavy metals. The agents used to dye materials are soluble dyes and insoluble pigments. They are distinguished by a high ability to selectively absorb light and can permanently colour other objects. The metallic pigments made of aluminium, copper, zinc and their alloys are commonly used for printing on foils. Stabilisers prevent degradation of the polymer under the influence of oxidation, UV radiation or elevated temperature. Soot, lead compounds and organic metal salts are used for this purpose [Hummel 2002, Hahladakis 2018].

Due to the wide use of compounds of various metals for the production and colouring of materials made of biodegradable and oxo-biodegradable polymers, an attempt was made to assess the possibility of environmental pollution with metals released during their decomposition [Ohidul et al. 2018a]. The results of analysis pertaining to the content of selected metals in waste sacks and shopping bags are presented in this work. The research was conducted on new and composted packaging. The aim of the research was to determine the possibilities of:

- decomposition of selected sacks and shopping bags along with biowaste collected in them,

- pollutants entering the produced compost.

\section{MATERIALS AND METHODS}

\section{Preparation of samples}

Table 1 presents the characteristics of selected waste sacks and shopping bags, which were subject to decomposition under the actual conditions of an industrial composting plant. The sacks and bags commonly used in the trade were used. According to the manufacturers' information, all of them were made of compostable, oxo-biodegradable or biodegradable raw materials, which should be decomposed under the influence of microorganisms. The samples of about $500 \mathrm{~cm}^{2}$ were cut out from the sacks and bags.

According to the manufacturers' instructions, in order for an oxo-biodegradable sample to decompose, it must be exposed to UV radiation and thermal energy. In industrial composting plants, such conditions can only be obtained when collecting waste in hopper bunkers. This is impossible later on, because the reactors in which the first stage of composting is carried out are in sealed equipment, with no UV radiation. Therefore, after excision, all samples were exposed to a $36 \mathrm{~W}$ UV lamp in 20- and 50-hour cycles, which corresponded to the storage of waste in the bunker for 2 to 5 days.

After the irradiation trial was completed, the samples were closed in coated fibreglass mesh, resistant to heat and UV rays [Bunsell 2009]. Individual samples were combined with clamps re- 
Table 1. Characteristics of selected samples [own study based on information from producers]

\begin{tabular}{|c|c|c|c|c|c|c|}
\hline \multirow{2}{*}{\begin{tabular}{|c|} 
Sample \\
num- \\
ber
\end{tabular}} & \multirow{2}{*}{$\begin{array}{c}\text { Type of raw material/ } \\
\text { polymer }\end{array}$} & \multirow{2}{*}{ Manufacturer's information } & \multicolumn{4}{|c|}{ Characteristics of the polymer } \\
\hline & & & form & colour & use & type \\
\hline 1. & $\begin{array}{l}\text { Compostable in indus- } \\
\text { trial conditions, } 2 \text { certifi- } \\
\text { cates in accordance with } \\
\text { norm EN } 13432\end{array}$ & $\begin{array}{l}\text { There is no need to re- } \\
\text { move from the stream of } \\
\text { bio-waste at the compost- } \\
\text { ing industry }\end{array}$ & foil, elastic, soft & $\begin{array}{l}\text { milky, translu- } \\
\text { cent, imprinted }\end{array}$ & $\begin{array}{l}\text { bags for biode- } \\
\text { gradable waste }\end{array}$ & $\begin{array}{c}\text { biodegradable, } \\
\text { compostable }\end{array}$ \\
\hline 2. & $\begin{array}{l}\text { Compostable at home } \\
\text { conditions, } 2 \text { certificates } \\
\text { in accordance with norm } \\
\text { EN } 13432\end{array}$ & $\begin{array}{l}\text { It is degraded in compost- } \\
\text { ing conditions in a period of } \\
\text { approximately } 45 \text { days }\end{array}$ & $\begin{array}{l}\text { foil, elastic, } \\
\text { soft, thin, rub- } \\
\text { ber }\end{array}$ & $\begin{array}{c}\text { milky, green, } \\
\text { translucent }\end{array}$ & $\begin{array}{l}\text { bags for biode- } \\
\text { gradable waste }\end{array}$ & $\begin{array}{c}\text { biodegradable, } \\
\text { compostable }\end{array}$ \\
\hline 3. & $\begin{array}{l}\text { Compostable, certificate } \\
\text { in accordance with norm } \\
\text { EN } 13432\end{array}$ & $\begin{array}{l}\text { Made on the basis of corn } \\
\text { and potato starch, decom- } \\
\text { posed by bacteria from } 6 \\
\text { weeks to one year }\end{array}$ & $\begin{array}{l}\text { foil, elastic, } \\
\text { soft, starch } \\
\text { coating }\end{array}$ & $\begin{array}{l}\text { green, opaque, } \\
\text { matt, imprinted }\end{array}$ & $\begin{array}{c}\text { packaging } \\
\text { of products, } \\
\text { including food- } \\
\text { stuffs }\end{array}$ & $\begin{array}{c}\text { biodegradable, } \\
\text { compostable }\end{array}$ \\
\hline 4. & $\begin{array}{l}\text { Oxo-biodegradable, } \\
\text { HDPE and } \mathrm{d} 2 \mathrm{w} \text { additive }\end{array}$ & $\begin{array}{l}\text { It is decomposed under } \\
\text { the influence of oxygen, } \\
\text { UV and heat, use within } 18 \\
\text { months }\end{array}$ & $\begin{array}{l}\text { foil, elastic, } \\
\text { soft, matt }\end{array}$ & $\begin{array}{l}\text { milky, white, } \\
\text { translucent, } \\
\text { imprinted }\end{array}$ & $\begin{array}{c}\text { packaging } \\
\text { of products, } \\
\text { including food- } \\
\text { stuffs }\end{array}$ & $\begin{array}{l}\text { oxo-biodegrad- } \\
\text { able }\end{array}$ \\
\hline 5. & $\begin{array}{l}\text { Oxo-biodegradable, PE } \\
\text { and TDPA additive }\end{array}$ & $\begin{array}{l}\text { It is subject to accelerated } \\
\text { decomposition }\end{array}$ & $\begin{array}{c}\text { foil, elastic, } \\
\text { slippery to the } \\
\text { touch }\end{array}$ & $\begin{array}{c}\text { orange, } \\
\text { imprinted, } \\
\text { opaque, glossy }\end{array}$ & $\begin{array}{l}\text { packaging of } \\
\text { products }\end{array}$ & $\begin{array}{l}\text { oxo-biodegrad- } \\
\text { able }\end{array}$ \\
\hline 6. & $\begin{array}{l}\text { Biodegradable, LDPE } \\
\text { and sugar cane }\end{array}$ & $\begin{array}{l}\text { Sugar cane content above } \\
85 \% \text {, renewable raw mate- } \\
\text { rial, } 100 \% \text { recyclable }\end{array}$ & $\begin{array}{l}\text { foil, elastic, } \\
\text { slippery to the } \\
\text { touch }\end{array}$ & $\begin{array}{l}\text { white, opaque, } \\
\text { glossy, im- } \\
\text { printed }\end{array}$ & $\begin{array}{c}\text { packaging } \\
\text { of products, } \\
\text { including food- } \\
\text { stuffs }\end{array}$ & biodegradable \\
\hline 7. & $\begin{array}{l}\text { Oxo-biodegradable, } \mathrm{PE} \\
\text { and } \mathrm{d} 2 \mathrm{w} \text { additive }\end{array}$ & $\begin{array}{l}\text { Thanks to the addition of } \\
\mathrm{d} 2 \mathrm{w} \text {, the bag is } 100 \% \text { bio- } \\
\text { degradable }\end{array}$ & $\begin{array}{l}\text { foil, elastic, } \\
\text { slippery to the } \\
\text { touch }\end{array}$ & $\begin{array}{c}\text { white, opaque, } \\
\text { glossy }\end{array}$ & $\begin{array}{c}\text { packaging } \\
\text { of products, } \\
\text { including food- } \\
\text { stuffs }\end{array}$ & $\begin{array}{l}\text { oxo-biodegrad- } \\
\text { able }\end{array}$ \\
\hline 8. & $\begin{array}{l}\text { Oxo-biodegradable, } \\
\text { HDPE }\end{array}$ & $\begin{array}{l}\text { The bag is oxo-biodegra- } \\
\text { dated } 100 \%\end{array}$ & $\begin{array}{l}\text { foil, elastic, } \\
\text { soft, slippery to } \\
\text { the touch }\end{array}$ & $\begin{array}{l}\text { milky, white, } \\
\text { imprinted, } \\
\text { opaque }\end{array}$ & $\begin{array}{c}\text { packaging } \\
\text { of products, } \\
\text { including food- } \\
\text { stuffs }\end{array}$ & $\begin{array}{l}\text { oxo-biodegrad- } \\
\text { able }\end{array}$ \\
\hline 9. & $\begin{array}{l}\text { Oxo-biodegradable, } \\
\text { HDPE and d2w additive }\end{array}$ & $\begin{array}{l}\text { It has the Oxo-biodegrad- } \\
\text { able Plastics Association } \\
\text { mark }\end{array}$ & $\begin{array}{l}\text { foil, rigid, slip- } \\
\text { pery to the } \\
\text { touch }\end{array}$ & $\begin{array}{l}\text { milky, white, } \\
\text { translucent, } \\
\text { matt }\end{array}$ & $\begin{array}{c}\text { packaging } \\
\text { of products, } \\
\text { including food- } \\
\text { stuffs }\end{array}$ & $\begin{array}{l}\text { oxo-biodegrad- } \\
\text { able }\end{array}$ \\
\hline 10. & $\begin{array}{l}\text { Oxo-biodegradable, } \\
\text { HDPE }\end{array}$ & $\begin{array}{l}\text { The bag is oxo-biodegra- } \\
\text { dated } 100 \%\end{array}$ & $\begin{array}{c}\text { foil, elastic, } \\
\text { slippery to the } \\
\text { touch }\end{array}$ & $\begin{array}{l}\text { white, opaque, } \\
\text { glossy, im- } \\
\text { printed }\end{array}$ & $\begin{array}{c}\text { packaging } \\
\text { of products, } \\
\text { including food- } \\
\text { stuffs }\end{array}$ & $\begin{array}{l}\text { oxo-biodegrad- } \\
\text { able }\end{array}$ \\
\hline
\end{tabular}

sistant to the temperatures occurring during composting. All samples prepared in this way were placed in bioreactor in industrial composting plant (inside a waste heap) [Adamcova, Vaverkova 2014]. In total, four samples were prepared for each tested sack (bag):

a) new packaging,

b) packaging composted without irradiation,

c) packaging composted after irradiation for

20 hours,

d) packaging composted after irradiation for 50 hours.

Due to the limited amount of biodegradable waste, delivered to the reactor at one time, the tested set of samples consisted of: 10 samples of new packaging, 10 samples irradiated before composting over a period of 20 hours and 10 samples irradiated before composting over a period of 50 hours. Each set consisted of 30 samples placed under similar conditions. Subsequent sets of samples were placed in the reactors, along with successive batches of waste, the composting of which was completed at a later time. The paper presents the results of testing the set of samples placed in the reactor on July 24, 2017.

After the completion of the composting process, the samples were removed from the compost heap, thoroughly washed and dried. Tap water was used for cleaning, and at the end, the samples were thoroughly rinsed with distilled water. Drying took place at room temperature. The samples that were washed out of the net, were considered completely decomposed, due to the fact that under real conditions (without the nets) it would be impossible to separate them from the composted waste.

The washed and dried samples were removed from the nets and subjected to a visual assessment, which was a supplement to the photographic documentation. Visual assessment allows to identify 
the changes in the appearance and structure of the samples (discolouration, surface roughness), which indicate the beginning of the decomposition process but do not affect the chemical composition of the samples yet. Then, the samples were prepared for the procedure of determining the content of selected metals.

\section{COMPOSTING}

The research on the decomposition of selected sacks for waste and shopping bags was conducted in a composting plant located in Jarocin (Waste Treatment Plant in Jarocin, Greater Poland Voivodeship, Poland). The composting plant uses the biodome technology, with a closed and actively aerated reactor, equipped with a flue gas cleaning installation. In this technology, solar radiation and process heat are used to maintain the appropriate temperature level inside the reactor, thanks to which one may reduce the electricity consumption. The composting process takes place in two stages - the first stage occurs in the reactor, the second in the prism square. The temperature measurement in the reactor is automatic. The processing capacity of the composting plant is $5200 \mathrm{~m}^{3} /$ year. The composting plant processes a selectively collected organic fraction of municipal waste (leaves, grass, kitchen waste, fragmented branches, etc.). The selective collection of this waste in the area served by the composting plant in Jarocin has been conducted for a short time, therefore, at one time, relatively small amounts of waste are placed in the reactor, in which a limited number of plastic samples can be placed. The composting process takes about 5 months. The first stage (composting in the reactor) lasts two months, the second stage (maturation of compost) takes place in the compost heap area and lasts about 3 months, depending on the weather conditions ${ }^{1}$.

Figure 1 shows the temperature curve during the composting of the analysed samples in the reactor of the composting plant in Jarocin. The process lasted two months, from July 24, 2017 to September 26, 2017. The course of the process was monitored and controlled. High temperature ensures hygienisation of the waste and the development of microorganisms responsible for their decomposition. Aeration of the reactor takes place automatically. After the reactor was emptied, the pre-composted material matured in compost heaps for 3 months.

Composting is the process of converting the biodegradable materials into a humus-like substance, called compost. It is a controlled process, consisting of mesophilic and thermophilic phases, and the final product is a stabilised organic matter [Shah et al. 2008]. The finished product, i.e.compost, can be used, for example, in agriculture as a fertilizer. It is important to note that it does not contain harmful substances that can accumulate in the soil. The plastic bags brought for composting plant should disintegrate during composting so that the remaining fragments would be difficult to identify in the finished compost [Javierre et al. 2015], and should not cause deterioration of its properties.

\section{CHEMICAL ANALYSIS}

In the selected samples, the content of constituents that could pose a threat to the environment in the event of penetration from the material into the compost, was determined.

The content of the selected components was determined in new plastic samples, in the samples subjected to composting without irradiation and

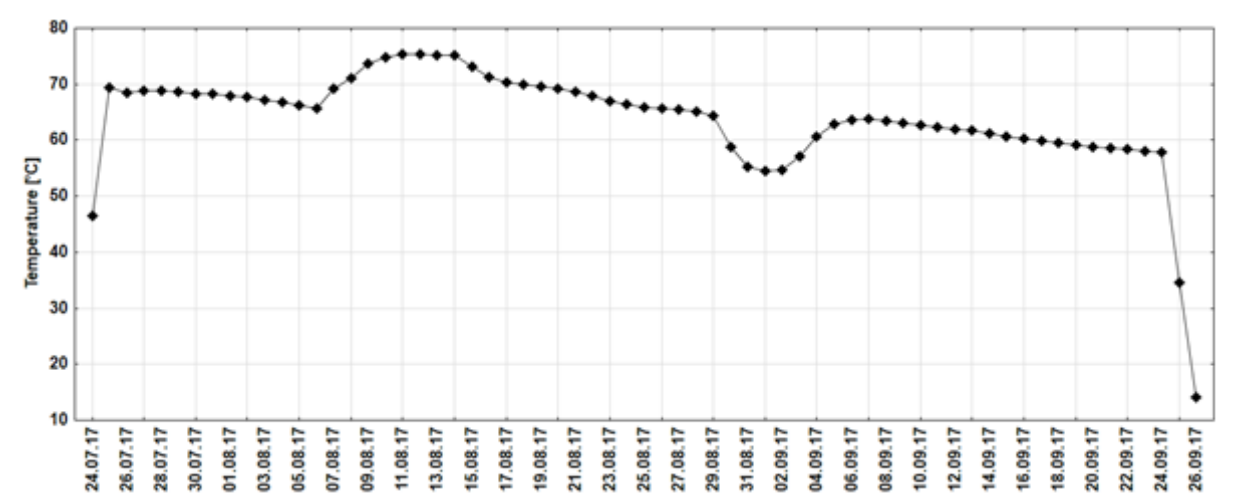

Fig. 1. The temperature curve during the first stage of composting in the industrial composting plant in Jarocin 
in the samples subjected to irradiation for 20 and 50 hours. Laboratory analyses were conducted after dissolution (mineralisation) in a mixture of concentrated acids: nitric (V) $-\mathrm{HNO}_{3}$, chlorine (VII) $-\mathrm{HClO}_{4}$ and sulphuric (VI) $-\mathrm{H}_{2} \mathrm{SO}_{4}$, prepared in the ratios of 10: 4: 1 [Baranowska 2015]. The contents of sodium, potassium, calcium, magnesium, iron, manganese, zinc, copper, chromium, lead, nickel, and cadmium in dissolved samples were determined by means of Atomic Absorption Spectrometry (AAS), which uses the phenomenon of radiation absorption at a specific wavelength by atoms of the element [Yang et al. 2010, Żernicki 2010, Samadi et al. 2015].

The results of the research on the plastics composition were subjected to the statistical analysis using the Statistica 13.1 software package (StatSoft Poland, StatSoft, Inc. USA). Due to the possibility of one-time composting of a limited number of samples, the performed statistical analyses were divided into: new samples (marked on the charts by letter A), composted samples not subjected to irradiation (B), compressed samples irradiated with UV rays over a period of 20 hours (C) and composited samples irradiated with UV rays over a period of 50 hours (D). Too small number of observations did not enable to analyse the changes in the composition of plastics differentiating them between biodegradable and oxobiodegradable, nor individual samples.

\section{RESULTS}

During the composting process of samples made of biodegradable and oxo-biodegradable polymers, all samples No. 1 and 2 (without irradiation and after irradiation) were followed by a complete decomposition. Figure 2 shows the appearance of selected samples before composting

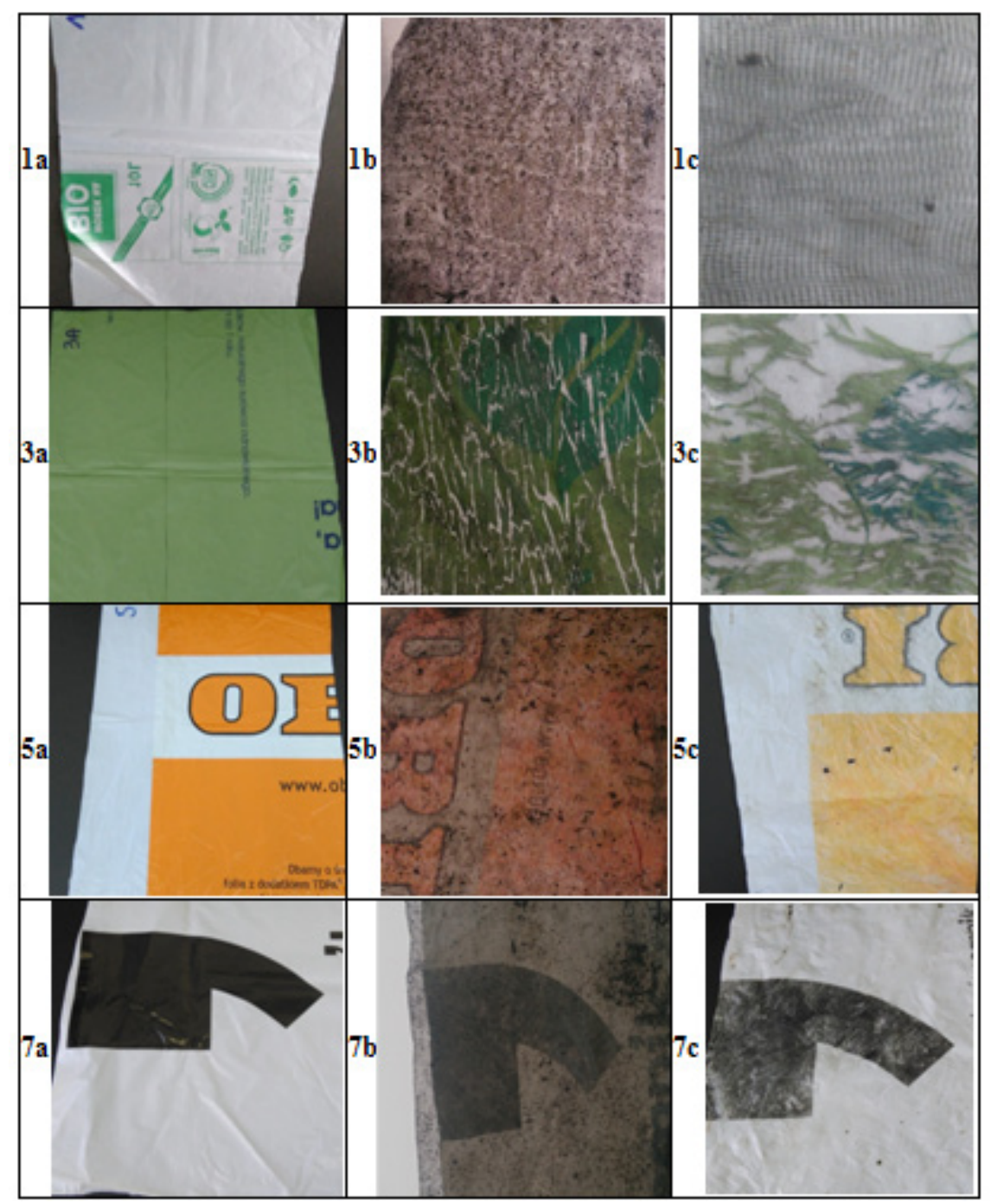

Fig. 2. Appearance of samples 1, 3, 5 and 7: a) new, b) after the composting process, c) after rinsing and drying 
(a), after the composting process (b) and after rinsing and removal from the net - in the case of sample No. 1 the net was empty.

Sample No. 3 disintegrated into distinct fragments. In the structure of the remaining samples, no such significant changes were observed. Some were slightly discoloured, became duller and roughened, but there were also the samples (Nos. 6 and 10) that retained a distinct colour and elasticity. Flexibility was also evident in samples 7 and 8.

Oxo-biodegradable samples, containing TDPA $^{\circledR}$ or $\mathrm{d} 2 \mathrm{w}^{\circledR}$ supplements exposed to irradiation (both 20- and 50-hour) showed greater structural changes than those that were not. Such observations were also made by Corti [Corti et al. 2010], among others, who showed that thanks to exposure to solar radiation and subsequent biodegradation of vaccinated mushrooms, the degradation process took place over a shorter period.

Other authors indicated that the composted materials with the addition of TDPA ${ }^{\circledR}$ (crushed and mixed with waste) will decompose within 1-4 months [Raninger et al. 2002]. The research conducted in the composting plant in Jarocin did not indicate such clear changes (e.g., sample No. 5), however the trials were not fragmented.

Figures 3-5 present the results pertaining to the analyses of selected metals (sodium, potassium, calcium, magnesium, iron, manganese, zinc, copper, chromium, lead, nickel, and cadmium). The contents were determined in new plastic samples (marked with the letter A), in the samples subjected to composting without irradiation (B) and in samples subjected to irradiation for 20 (C) and 50 (D) hours.

The analysis of the content of the selected twelve metals in new samples of materials from biodegradable and oxo-biodegradable polymers indicated the highest calcium content $(4044.91 \mathrm{mg}$ $\mathrm{Ca} / \mathrm{kg}$ on average) and potassium (196.19 mg $\mathrm{K} / \mathrm{kg}$ on average). High levels of magnesium (191.86 mg Mg/kg on average), iron (135.5 mg $\mathrm{Fe} / \mathrm{kg}$ on average) and zinc (97.36 $\mathrm{mg} \mathrm{Zn} / \mathrm{kg}$ on average) were also found in the materials. Nickel ( $2.72 \mathrm{mg} \mathrm{Ni} / \mathrm{kg}$ on average) and cadmium $(0.24 \mathrm{mg} \mathrm{Cd} / \mathrm{kg}$ on average) were found in the smallest quantities. The knowledge on the content of the analysed components is important, as

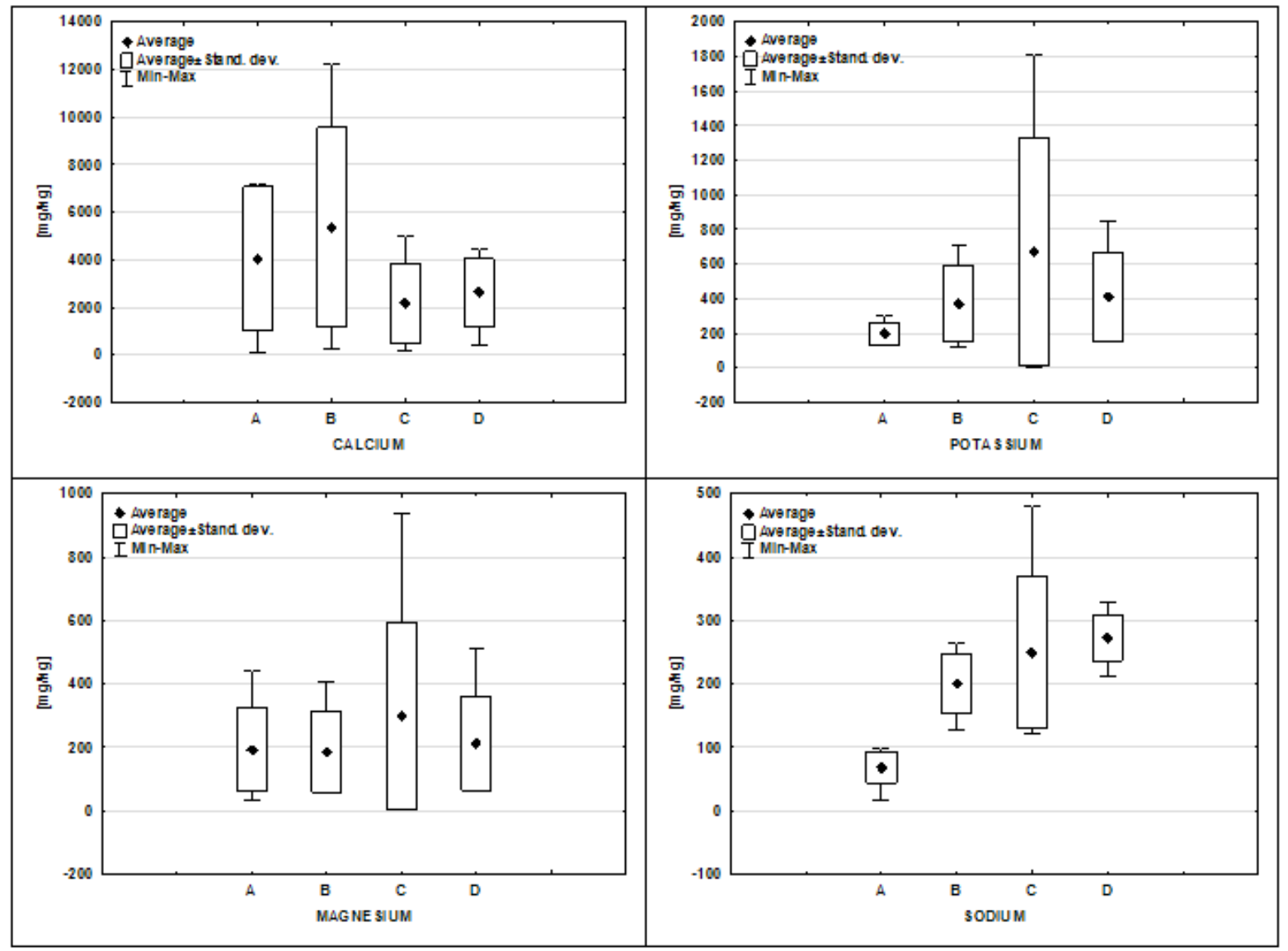

Fig. 3. Characteristic values (average, standard deviation, minimum, maximum) of calcium, potassium, magnesium and sodium in the materials from biodegradable and oxo-biodegradable polymers 


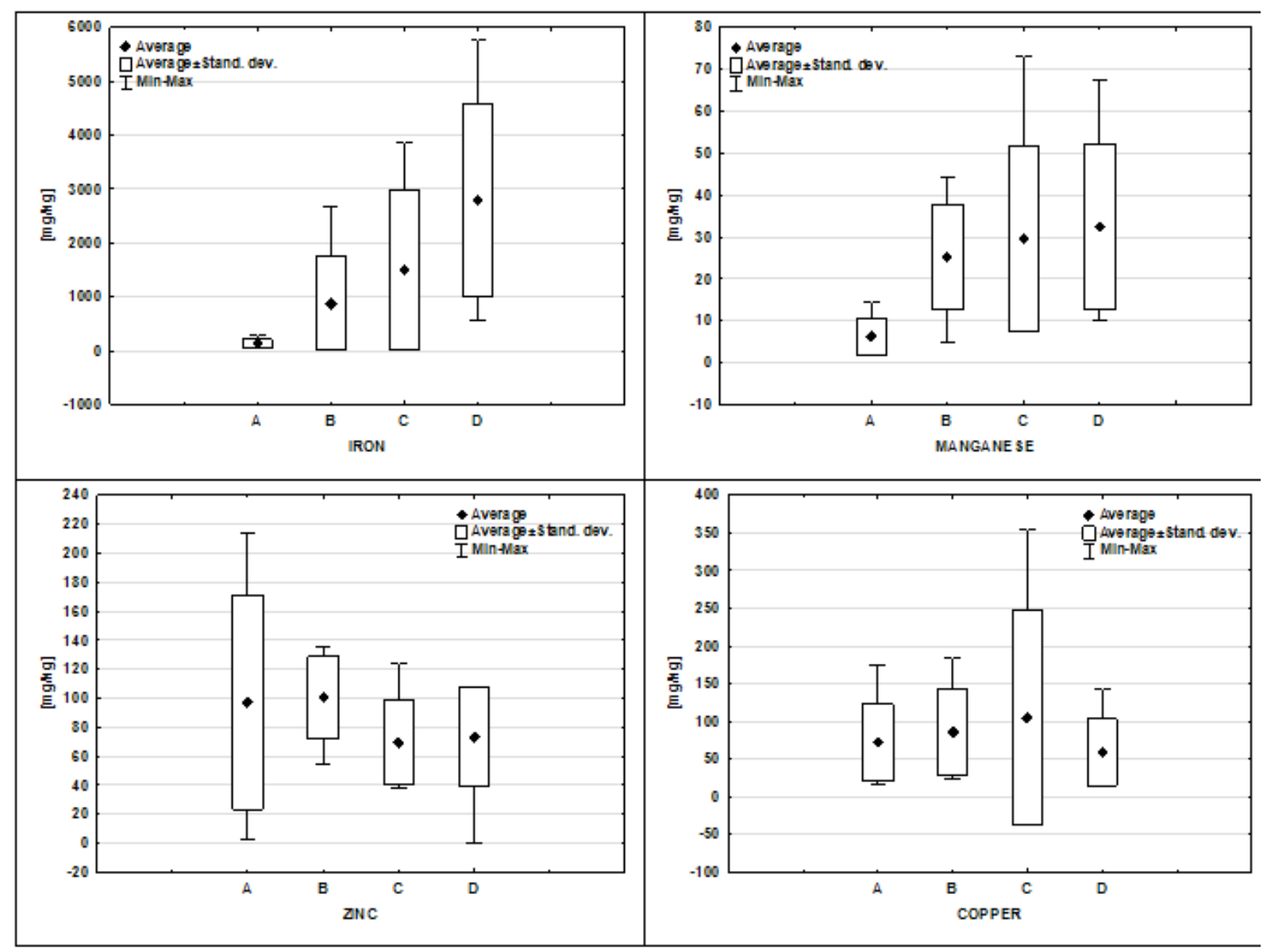

Fig. 4. Characteristic values (average, standard deviation, minimum, maximum) of iron, manganese, zinc and copper in the materials from biodegradable and oxo-biodegradable polymers

those are the maximum amounts that can enter the environment during the composting process (as in all variants of samples 1 and 2, which have been completely decomposed) [Ohidul et al. 2018a].

In the composted samples of non-irradiated packaging, calcium $(5326 \mathrm{mg} \mathrm{Ca} / \mathrm{kg}$ on average) and iron (877.06 mg Fe/kg on average) were present in the largest quantities. The plastics also contained high amounts of potassium $(372.25 \mathrm{mg}$ $\mathrm{K} / \mathrm{kg}$ on average), sodium (201.57 $\mathrm{mg} \mathrm{Na} / \mathrm{kg}$ on average), and magnesium (185.86 $\mathrm{mg} \mathrm{Mg} / \mathrm{kg}$ on average), while lead ( $0.34 \mathrm{mg} \mathrm{Pb} / \mathrm{kg}$ on average) and cadmium $(0.0028 \mathrm{mg} \mathrm{Cd} / \mathrm{kg}$ on average $)$ were found in the smallest quantities. The changes in the content may have been caused by two mechanisms - the release of some components into the environment (causing a decrease in the content in the samples after composting - like in the case of sodium, potassium, calcium, iron, manganese and chromium contents) and the concentration of the remaining components (visible as an increase in the content in trials after composting, e.g. magnesium, lead, cadmium).
The samples irradiated with UV rays for 20 hours, after composting contained the most calcium $(2175.57 \mathrm{mg} \mathrm{Ca} / \mathrm{kg}$ on average). Iron (1492.57 $\mathrm{mg} \mathrm{Fe} / \mathrm{kg}$ on average) and potassium were found in smaller quantities $(671.86 \mathrm{mg}$ $\mathrm{K} / \mathrm{kg}$ on average). High magnesium (297.37 mg $\mathrm{Mg} / \mathrm{kg}$ on average) and copper (105.12 $\mathrm{mg} \mathrm{Cu} / \mathrm{kg}$ on average) content was also found in the samples, while lead ( $2.62 \mathrm{mg} \mathrm{Pb} / \mathrm{kg}$ on average) and cadmium $(0.0028 \mathrm{mg} \mathrm{Cd} / \mathrm{kg}$ on average) were found in the smallest quantities. For new samples, the increase in the content was observed in the case of sodium, potassium, magnesium and iron, whereas calcium, zinc, lead and cadmium were characterized by a decreased content.

The samples irradiated with UV rays for 50 hours, after composting exhibited mostly iron (2795.68 $\mathrm{mg} \mathrm{Fe} / \mathrm{kg}$ on average), and calcium (2623.88 $\mathrm{mg} \mathrm{Ca} / \mathrm{kg}$ on average) content. Potassium (408.28 mg K/ $\mathrm{kg}$ on average) and sodium (273.0 $\mathrm{mg} \mathrm{Na} / \mathrm{kg}$ on average) were also found in large quantities, while nickel $(7.08 \mathrm{mg} \mathrm{Ni} / \mathrm{kg}$ on average) and chromium (7.21 mg $\mathrm{Cr} / \mathrm{kg}$ on aver- 


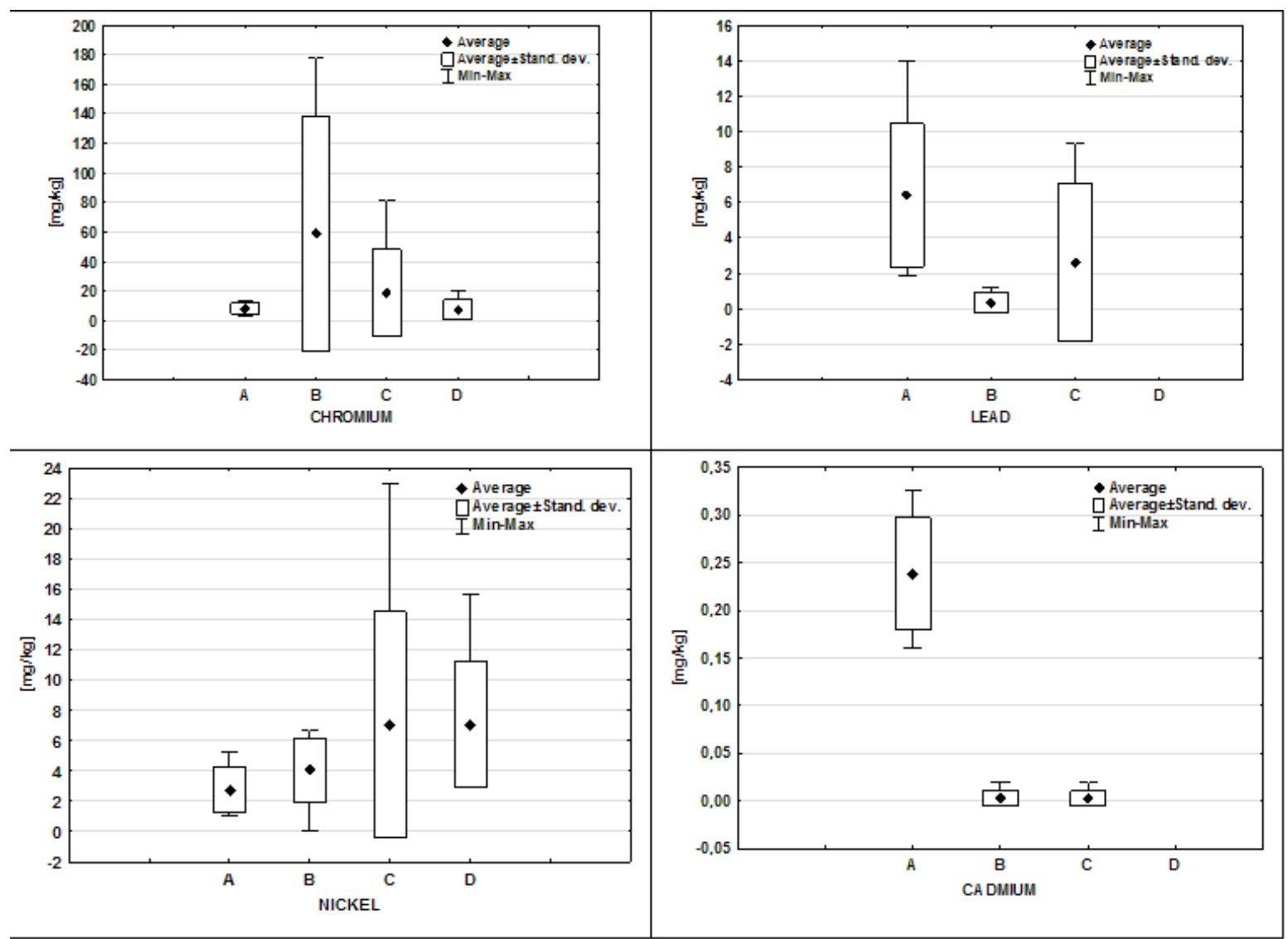

Fig. 5. Characteristic values (average, standard deviation, minimum, maximum) of chromium, lead, nickel and cadmium in the materials from biodegradable and oxo-biodegradable polymers

age) were found in the least amount. The presence of lead and cadmium was not detected in any of the samples. Compared to new samples, the contents of iron, potassium, sodium, manganese and nickel increased after composting, while the content of calcium, zinc, copper, chromium and nickel decreased.

The conducted research on the content of selected metals in the samples of materials from biodegradable and oxo-biodegradable polymers indicated a large variation in the obtained results. The macronutrients such as: calcium, iron, magnesium, sodium, and potassium were found in the largest amounts. Although these are the elements naturally present in the environment in large quantities, supplying them to the soil together with compost from waste can lead to exceeding safe levels for the environment (e.g., in the case of trial No. 3). An example may be magnesium, the excess of which may limit the uptake of other elements, e.g., potassium. However, the excess of calcium may be manifested by the dying of plants and the higher $\mathrm{pH}$ disturbs the water and other components [Jaishankar et al. 2014, Warne 2014].
The analysis of the heavy metals content (zinc, copper, chromium, lead, nickel, and cadmium) indicated their presence in all tested plastic samples. Most of these pollutants were in samples no. $6,8,9$, and 10 , although trial no. 6 was described by the manufacturer as made at least $85 \%$ from natural raw materials, and trials 8,9 , and 10 are oxo-biodegradable. The source of metals in the studied materials could be used for the production of additives, such as dyes, fillers, antioxidants, stabilizers or softeners. In the tested samples of oxobiodegradable and biodegradable plastics, the content of chromium and manganese was higher than that of traditional plastics (PE, HDPE, LDPE, PVC). The contents of lead, zinc and copper were similar. The cadmium contents in the tested materials were significantly lower [Ohidul et al. 2018b]. Taking into account the fact that heavy metals are able to accumulate in the environment, supplying them with compost made from waste can lead to contamination of the soil on which the compost will be used. Even if the content of heavy metals in the studied materials were not too high, the spread of their use for biowaste collection resulting in an increased share in 
the composted mass, may lead to a deterioration of the quality of the soil or water environment.

\section{CONCLUSIONS}

1. Biodegradable and oxo-biodegradable sacks (or shopping bags) are readily used by consumers to collect waste for composting. However, the additives used for their production (dyes, fillers, antioxidants, stabilisers, softeners), contain heavy metals compounds (zinc, cadmium, lead, nickel, copper, chromium, cobalt, iron, manganese), which can infiltrate into the environment during biodegradation.

2. The research results presented in the work indicated that many sacks (bags) made of biodegradable and oxo-biodegradable plastics were not degraded in conditions of industrial composting. Only two of the ten analysed samples were completely degraded during composting. The third was clearly fragmented. Among those remaining, some indicated slight changes in colour or structure, but there were also the samples which did not differ significantly after composting from the new ones.

3. The results of the analysis of the content of selected metals (sodium, potassium, calcium, magnesium, iron, manganese, zinc, copper, chromium, lead, nickel and cadmium) showed wide variation, both in new plastics and after their composting. Changes in the content may have been caused by two mechanisms - the release of some components into the environment (causing a decrease in the content in the samples after composting) and the concentration of the remaining components (visible as an increase in the content in trials after composting).

4. The conducted analyses also showed the varied nature of changes in the composition of plastics, depending on the UV irradiation conducted. Some of the metals tested (chromium, lead, nickel) occurred in smaller quantities in the samples subjected to irradiation in the long term. This was particularly evident in the case of cadmium and lead, which were not found in the majority of the analysed samples (4-10) exposed to UV radiation over a period of 50 hours.

5 . The research results presented in the paper indicated that the biodegradable and oxo-biodegradable plastic waste can be a source of pollution, released into the environment. Due to the varied nature of the changes identified, it is advisable to continue the research, which will enable to determine the desired method of their recovery or disposal.

\section{Acknowledgements}

The research was carried out as part of a targeted subsidy for research and development of young scientists and $\mathrm{PhD}$ students at the Faculty of Environmental Engineering and Geodesy of the Wrocław University of Environmental and Life Sciences - contract no. B030/0101/17.

\section{REFERENCES}

1. Act of 13 June 2013 on the management of packaging and packaging waste. (the unified text) Journal of Laws 2018, item 150 [in Polish].

2. Adamcová D., Vaverková M. 2014. Biodegradation of Degradable/Biodegradable Plastic Material in Controlled Composting Environment. Polish Journal of Environmental Studies, 23(5), 1465-1474.

3. Álvarez-Chávez C.R., Edwards S., Moure-Eraso R., Geiser K. 2012. Sustainability of bio-based plastics: general comparative analysis and recommendations for improvement. Journal of Cleaner Production, 23, 47-56.

4. Bahramian B., Fathi A., Dehghani F. 2016. A renewable and compostable polymer for reducing consumption of non-degradable plastics. Polymer Degradation and Stability, 133, 174-181.

5. Baranowska I. (ed.) 2015. Handbook of trace analysis. Fundamentals and applications. Springer Cham Heidelberg New York Dordrecht London.

6. biodeg.org (13.02.2018)

7. Bunsell A. R. (ed.) 2009. Handbook of Tensile Properties of Textile and Technical Fibres. Woodhead Publishing Limited, Abington Hall.

8. Corti A., Muniyasamy S., Vitali M., Imam S. H., Chiellini E. 2010. Oxidation and biodegradation of polyethylene films containing pro-oxidant additives: Synergistic effects of sunlight exposure, thermal aging and fungal biodegradation. Polymer Degradation and Stability, 95(6), 1106-1114.

9. EN 13432:2000 Packaging - Requirements for packaging recoverable through composting and biodegradation - Test scheme and evaluation criteria for the final acceptance of packaging.

10. epi-global.com/en/about-tdpa.php (13.02.2018)

11. Hahladakis J.N., Velis C.A., Weber R., Iacovidou E., Purnell P. 2018. Journal of Hazardous Materials, 344, 179-199. 
12. Hummel D.O. 2002. Atlas of Plastic Additives. Analysis by Spectrometric Methods. Springer-Verlag Berlin Heidelberg New York.

13. Jacobsen R., Willeghems G., Gellynck X., Buysse J. 2018. Increasing the quantity of separated postconsumer plastics for reducing combustible household waste: The case of rigid plastics in Flanders. Waste Management, 78, 708-716.

14. Jaishankar M., Tseten T., Anbalagan N., Blessy B. M., Beeregowda K.N. 2014. Toxicity, mechanism and health effects of some heavy metals. Interdisciplinary Toxicology, 7(2), 60-72.

15. Javierre C., Sarasa J., Claveria I., Fernandez A. 2015. Study of the Biodisintegration on a Painted Bioplastic Material Waste. MATERIALE PLASTICE, 52(1), 116-121.

16. Lithner D., Larsson A., Dave G. 2011. Environmental and health hazard ranking and assessment of plastic polymers based on chemical composition. Science of The Total Environment, 409(18), 3309-3324.

17. Ohidul A., Mukaddis B., Ding Y. 2018a. Characteristics of plastic bags and their potential environmental hazards. Resources, Conservation \& Recycling, 132, 121-129.

18. Ohidul A., Sijia W., Wentao L. 2018b. Heavy metals dispersion during thermal treatment of plastic bags and its recovery. Journal of Environmental Management, 212, 367-374.

19. okcompost.be (23.02.2018).

20. Pivnenko K., Eriksen M.K., Martín-Fernández J.A., Eriksson E., Astrup T.F. 2016. Recycling of plastic waste: Presence of phthalates in plastics from households and industry. Waste Management, 54, 44-52.

21. Raninger B., Steiner G., Wiles D.M., Hare C.W.J. 2002. Tests on composting of degradable polyethylene in respect to the quality of the end product compost. In: Insam H., Riddech N., Klammer S. (eds) Microbiology of Composting. Springer, Berlin, Heidelberg, 299-308.

22. Regulation of the Minister of Agriculture and Rural Development of 18 June 2008 on the implementation of certain provisions of the Act on fertilizers and fertilization (Journal of Laws of 2008, No. 119, item 765), [in Polish].

23. Rochman C.M., Browne M.A, Halpern B.S., Hentschel B.T., Hoh E., Karapanagioti H.K., RiosMendoza L.M., Takada H., The S., Thompson R.C. 2013. Classify plastic waste as hazardous. Nature, 494, 169-171.

24. Samadi N., Hasanzadeh R., Rasad M. 2015. Adsorption isotherms, kinetic, and desorption studies on removal of toxic metal ions from aqueous solutions by polymeric adsorbent. Journal of Applied Polymer Science, 132(11), 41642.

25. Shah A.A., Hasan F., Hameed A., Safia A. 2008. Biological degradation of plastics: A comprehensive review. Biotechnology Advances, 26, 246-265.

26. Spierling S., Knüpffer E., Behnsen H., Mudersbach M., Krieg H., Springer S., Albrecht S., Herrmann C., Endres H-J. 2018. Bio-based plastics - A review of environmental, social and economic impact assessments. Journal of Cleaner Production, 185, 476-491.

27. Tang Z., Zhang L., Huang Q., Yang Y., Nie Z., Cheng J., Yang J., Wang Y., Chai M. 2015. Contamination and risk of heavy metals in soils and sediments from a typical plastic waste recycling area in North China. Ecotoxicology and Environmental Safety, 122, 2015, 343-351.

28. Warne R.W. 2014. The micro and macro of nutrients across biological scales. Integrative and Comparative Biology, 54(5), 864-872.

29. Wróblewska-Krepsztul J., Rydzkowski T., Borowski G., Szczypiński M.M., Klepka T., Thakur V.K., 2018. Recent progress in biodegradable polymers and nanocomposite-based packaging materials for sustainable environment. International Journal of Polymer Analysis and Characterization, 23(4), 383-395.

30. Yang L., Li Y., Wang L., Zhang Y., Ma X., Ye Z. 2010. Preparation and adsorption performance of a novel bipolar PS-EDTA resin in aqueous phase. Journal of Hazardous Materials, 180(1-3), 98-105.

31. Żernicki W., Borkowska-Burnecka J., Bulska E., Szmyd E. 2010. Analytical atomic spectrometry - theory and practice. Wydawnictwo Malamut, Warszawa, [in Polish]. 